\title{
ERRATUM
}

\section{Gene expression in major depressive disorder}

R Jansen, BWJH Penninx, V Madar, K Xia, Y Milaneschi, JJ Hottenga, AR Hammerschlag, A Beekman, N van der Wee, JH Smit, Al Brooks, J Tischfield, D Posthuma, R Schoevers, G van Grootheest, G Willemsen, EJ de Geus, DI Boomsma, FA Wright, F Zou, W Sun and PF Sullivan

Molecular Psychiatry (2016) 21, 444; doi:10.1038/mp.2015.94; published online 23 June 2015

Correction to: Molecular Psychiatry advance online publication, 26 May 2015; doi:10.1038/mp.2015.57

Following publication of the above article, the authors noticed that the Supplementary Figure legends were not published with the paper. The legends accompany this erratum. In addition, the Supplementary Tables were originally presented as PDF files. Excel versions of the tables have replaced the PDF versions linked to the paper. The publisher regrets the error. 